\title{
Chemical Characterization of Bio-oil from Pyrolysis of Undecayed and Decayed Fagus orientalis Wood
}

\section{Kemijska karakterizacija biološkog ulja dobivenoga pirolizom zdravoga i natrulog drva bukve (Fagus orientalis)}

\author{
Original scientific paper • Izvorni znanstveni rad \\ Received-prispjelo: 27. 4. 2016. \\ Accepted-prihvaćeno: 11. 5. 2017. \\ UDK: $630 * 813.4 ; 630 * 872.64 ; 674.031 .632 .22$ \\ doi:10.5552/drind.2017.1626
}

\begin{abstract}
Among forest diseases, fungi are the most important agents that cause irreparable losses to the wood of standing trees and logs. In this study, pyrolysis of undecayed and decayed beech (Fagus orientalis) wood were carried out using a fixed-bed reactor at pyrolysis temperature of $500{ }^{\circ} \mathrm{C}$ in nitrogen atmosphere. The influence of Trametes versicolor fungal decay on the yield and chemical composition of products was investigated. The bio-oil yield was $62.5 \mathrm{wt} \%$ at a pyrolysis temperature of $500{ }^{\circ} \mathrm{C}$ for decayed wood, while the bio-oil yield was found to be about $58 \mathrm{wt} \%$ at the same temperature for undecayed wood. Bio-oils were characterized using some chromatographic and spectroscopic techniques, such as gas chromatography-mass spectrometry (GC/MS). It was found that Tetracosamethyl-cyclododecasiloxane (5.50\%), tetradecamethyl-hexasiloxane (4.85\%), 2,6-dimethoxy-phenol $(4.21 \%)$, and benzene acetic acid (3.16\%) were the main oil components present in decayed beech wood, while syringol (14.86\%), methoxyeugenol (6.59\%), naphthalene (4.41\%), o-guaiacol (3.60\%), isoeugenol $(3.17 \%)$, and 2-methoxy-4-methyl-phenol (3.08\%) were present in undecayed beech wood. These results show that decayed wood can be used for the production of bio-oil.
\end{abstract}

Key words: beech wood, Trametes versicolor, pyrolysis, GC/MS, oil compound

SAŽETAK • Među šumskim štetnicima gljive su najopasniji činitelji koji uzrokuju nepovratne gubitke drva rastućih stabala i trupaca. U ovom je istraživanju provedena piroliza uzoraka od zdravoga i natrulog drva bukve (Fagus orientalis) u atmosferi dušika, uz pomoć fiksnog reaktora i pri temperaturi pirolize $500{ }^{\circ} \mathrm{C}$. Istraživan je utjecaj gljiva truležnica (Trametes versicolor) na prinose i kemijski sastav produkata pirolize tretiranog drva. Prinos biološkog ulja od natrulog drva pri temperaturi pirolize $500{ }^{\circ} \mathrm{C}$ bio je $62,5 \%$ (težinskog udjela), dok je prinos biološkog ulja od zdravog drva bio oko $58 \%$ (težinskog udjela) pri jednakoj temperaturi pirolize. Biološkog ulja su karakterizirana uz pomoć određenih kromatografskih i spektroskopskih tehnika kao što je plinska kromatografija / masena spektrometrija (GC/MS). Utvrđeno je da su glavne uljne komponente zastupljene u natruloj bukovini

\footnotetext{
${ }^{1}$ Author is associate professor at Department of Wood Science and Paper Technology, Karaj Branch, Islamic Azad University, Karaj, Iran. ${ }^{2}$ Author is M.Sc. at Department of Wood Science and Paper Technology, Karaj Branch, Islamic Azad University, Karaj, Iran. ${ }^{3}$ Author is professor at Department of Wood Science and Paper Technology, Karaj Branch, Islamic Azad University, Karaj, Iran. ${ }^{4}$ Author is associate professor at Department of Industrial Engineering, Engineering Faculty, Karabük University, Karabük 78050, Turkey

Autori su izvanredni profesori Odjela za znanost o drvu i tehnologiju papira, Islamsko sveučilište Azad, Karaj Branch, Karaj, Iran. ${ }^{2}$ Autor je profesor Odjela šumarstva i drvne tehnologije, Agronomski fakultet (EL-Shatby), Sveučilište Alexandria, Alexandria, Egipat. ${ }^{3}$ Autor je profesor Odjela za industrijsko inženjerstvo, Fakultet inženjerstva, Sveučilište Karabük, Karabük, Turska.
} 
tetracosametil-ciklododekasiloksan (5,50\%), tetradekametil-heksasiloksan (4,85\%), 2,6-dimetoksi-fenol (4,21 $\%$ i benzen octena kiselina (3,16\%), dok je u zdravom bukovu drvu bilo siringola (14,86\%), metoksieugenola (6,59\%), naftalena (4,41\%), o-gvajakola (3,60\%), izoeugenola (3,17\%) i 2-metoksi-4-metilfenola (3,08\%). Dobiveni rezultati pokazuju da se natrulo drvo može iskoristiti za proizvodnju biološkog ulja.

Ključne riječi: bukovina, Trametes versicolor, piroliza, GC/MS, uljni spoj

\section{INTRODUCTION}

\section{UVOD}

Growing population is followed by increasing demand for energy and chemical products and fossil fuel resources are not inexhaustible and their prices are increasing. Consequently, more attention is focused on wood as renewable raw material and its chemical components that lead to fuel. Pyrolysis technology has been investigated actively and has spread all over the world, to be utilized in bio-fuel production (Gardner and Schultz, 1985).

Wood is a natural polymer and a biological material having porous structure. Wood, like any other biological material, will be damaged by specific deteriorating agents. The most important deteriorating agents that cause irreparable losses to the wood of standing trees and logs are fungi (Hosoya et al., 2006).

Pyrolysis is a process in which materials are decomposed under heating condition in the presence of inert gas (without oxygen) or in the presence of an amount of controllable oxygen. Depending on the wood as raw material, the chemical products obtained from wood pyrolysis are turpentine, acetone, phenol, acetic acid, wood tar, syringol, resorsinol, etc (Faix et al., 1988).

High-resolution capillary columns in GC system have been used as a very efficient method in the analysis of organic complex compounds such as products obtained from wood pyrolysis, oil derivatives cracking, and also chemical and extractive materials as a complex mixture (Faix et al., 1988).

Pyrolysis compounds of white oak and lobbly pine woods determined by GC/MS technique have included lignin products such as guaiacol, 4-methyl guaiacol, 4- vinyl guaiacol, coniferaldehyde, coniferylaldehyde, vanillin, and also some products like guaiacol, 2-6-dimethoxy phenol, 4-methyl-2-6-methoxy phenol, syringaldehyde, and synapaldehyde (Dobele et al., 2007). Lignin, compared to other compounds in wood, is the most resistant. The highest rate of weight loss for lignin of milled spruce, beech and bamboo wood was obtained between 360 to $407^{\circ} \mathrm{C}$ (Obst, 1983; Tiilikkala et al., 2010).

Separation and identification of compounds in common walnut (Juglans regia) wood pyrolytic oils in a fixed bed reactor and in nitrogen atmosphere at $350{ }^{\circ} \mathrm{C}$ was done using GC/MS, where 10 compounds were identified, and most of them were related to levoglucosan and $\alpha$-L-galactopyranose that accounted for $49 \%$. These compounds were obtained by pyrolysis of cellulose and hemicellulose of wood structure (Schultz and Nicholas, 1977). Glycolaldehyde is not detectable in normal conditions and when GC is in- jected with pyrolytic wood, it was converted into other compounds; this compound was identified using silylation of oil compounds by N,O- bis (TMS) trifluoroacetamide (BSTFA); this method was introduced as one of the most appropriate techniques to investigate compounds obtained from wood pyrolysis (Hosoya et al., 2006).

This work was conducted to investigate the efficiency of pyrolysis method in wood conversion into important chemical compounds with significant added value, especially using decayed wood that are not usable in other applications. Research reports on pyrolysis of decayed beech wood is not extensive in the literature and since the decayed wood in forests is the most important source of contamination in forest standing trees, it would be economically feasible to find any application for decayed wood pyrolysis products and oil compounds.

\section{MATERIAL AND METHODS 2. MATERIJAL I METODE}

\subsection{Preparation of samples}

2.1. Priprema uzoraka

Beech wood (Fagus orientalis L.) samples were cut from a log harvested from Klardasht in the North of Iran. An unseasoned one meter long log was selected from a tree butt. The log averaged $500 \mathrm{~mm}$ in diameter. After being transferred to the laboratory, $1000 \times 300 \times 30 \mathrm{~mm}$ lumber was cut in the tangential direction of the $\log$, and the moisture content (MC) was measured gravimetrically. The lumber was seasoned at $60 \%$ relative humidity and $21{ }^{\circ} \mathrm{C}$ for 24 days to reach equilibrium moisture content. Then, some lumber was chosen randomly and decay samples were cut from this section. The dry test beech blocks $(50 \times 25 \times 15 \mathrm{~mm})$ were extracted using ethanol/ toluene $(1: 2 . \mathrm{v} / \mathrm{v})$ mixture for $6-8 \mathrm{~h}$. Then the extracted samples were dried at $60 \pm 5^{\circ} \mathrm{C}$ to constant weight and the weight was determined.

\subsection{Decay test \\ 2.2. Test truljenja}

In order to carry out the wood resistance test, white rot (Trametes versicolor) fungus was chosen as one of the three fungi sources to evaluate the natural resistance of wood. It was chosen according to BS $838: 1961$ standard test method. This fungus is considered fatal for hardwood species because it uses both cellulose and lignin (Farsi and Mirshokraei, 2011).

Samples were autoclaved at $120^{\circ} \mathrm{C}$ for $15 \mathrm{~min}$ and exposed to T. versicolor in Petri dishes containing $3 \%$ malt extract agar, pre-inoculated 1 week prior to the test. Samples were supported on sterile plastic 
mesh, and incubated at $25^{\circ} \mathrm{C}$ and $65 \%$ relative humidity for 14 weeks. At 14-week intervals, six beech samples were removed. Mycelium was removed from their surfaces and oven-dried to constant weight. The weight losses (WL) of individual samples were calculated according to Kolleschale method. The following Equation (1) was used for the calculation;

$$
W L(\%)=[(a-b) / a] \times 100
$$

Where $a$ and $b$ denote the oven dry weight of specimen prior to and after exposure to fungus, respectively.

After 14 weeks, some of the decayed samples were milled to produce wood flour. Decayed wood flour (DWF) was screened using a shaker prior to pyrolysis and chemical composition tests.

\subsection{Measurement of chemical compounds 2.3. Mjerenje kemijskih spojeva}

Measurement of chemical compounds of decayed wood flour (DWF) and undecayed wood flour (UDWF) was done according to relevant TAPPI standard test methods as follow: cellulose, T 264 om-88; extractives, T 207 om-97; Klason lignin, T 222 om-98; ash, T 211 om-93.

\subsection{Determination of pyrolysis temperature 2.4. Određivanje temperature pirolize}

A TGA-PL (Perkin Elmer, United Kingdom) microbalance from Iran Polymer and Petrochemical Research Institute was used for thermo-gravimetric tests. The DWF samples were heated from room temperature to $500{ }^{\circ} \mathrm{C}$, under a nitrogen flow of $150 \mathrm{~mL} / \mathrm{min}$ and heating rate of $10{ }^{\circ} \mathrm{C} / \mathrm{min}$. Milled samples of approximately $10 \mathrm{mg}$ were used. All tests were carried out twice to ensure reproducibility, and the average of two tests was reported.

\subsection{Pyrolysis tests}

2.5. Postupak pirolize

The pyrolysis test operating conditions were as follow: the total pressure inside the fixed-bed reactor was lower than $0.4 \mathrm{kPa}$, the final pyrolysis temperature was $500{ }^{\circ} \mathrm{C}$ and the heating rate was $10{ }^{\circ} \mathrm{C} / \mathrm{min}$. The reactor has a steel cylinder with an internal diameter of $6 \mathrm{~cm}$ and a height of $21 \mathrm{~cm}$. During the experiments, the heating rate and pyrolysis temperature were controlled with a PID (Proportional-IntegralDerivative) controller. The temperature was measured every minute in the reactor using a type $\mathrm{K}$ thermocouple. In the pyrolysis experiment, a sample was weighed and placed into the reactor, which was heated by an electric furnace. There were three step delays in heating; the first step was at $300{ }^{\circ} \mathrm{C}$, the second step at $400{ }^{\circ} \mathrm{C}$ and the third at $500{ }^{\circ} \mathrm{C}$. In each step of pyrolysis, the temperature was held constant for at least $15 \mathrm{~min}$. Pyrolysis temperature is known to influence pyrolysis yield. In pyrolysis studies found in literature, the pyrolytic oil reached a maximum value at 400-600 ${ }^{\circ} \mathrm{C}$ (Heo et al., 2010; Fagbemi et al,. 2001; Ozcifci and Özbay, 2013). The obtained oil was stored at $4{ }^{\circ} \mathrm{C}$ for future analysis.

\subsection{Silylation and GC/MS analysis}

2.6. Sililacija i GC/MS analiza

\subsubsection{Trimethylsilylation}

2.6.1. Trimetil sililacija

A $100 \mathrm{ml}$ pyrolysis oil sample was mixed with 100 $\mathrm{ml} \mathrm{N}$, O-bis (trimethylsilyl) trifluoroacetamide (BSTFA, Merck, Darmstadt, Germany), and $1 \mathrm{ml}$ diethyl ether was then added. The sample was then left for at least two hours (reaction time) at $70{ }^{\circ} \mathrm{C}$ in the water bath prior to the analysis of GC/MS. Analyses were conducted with a GC (HP 6890) equipped with a quadrupole mass selective detector (HP-5973series) (Agilent Technologies, Belgium). For all the analyses, the El electron energy was $70 \mathrm{ev}$ and the ion source temperature $250^{\circ} \mathrm{C}$. The sample was analyzed with a $30 \mathrm{~m} \times 0.25 \mu \mathrm{m}$ capillary column (HP-SMS), and the injector temperature was 70 ${ }^{\circ} \mathrm{C}$. The time-temperature program for the samples was 3 minutes at $60{ }^{\circ} \mathrm{C}$, then the temperature was increased to $250{ }^{\circ} \mathrm{C}$ at $6{ }^{\circ} \mathrm{C} / \mathrm{min}$, then to $280{ }^{\circ} \mathrm{C}$ at $20^{\circ} \mathrm{C} / \mathrm{min}$, and it was finally held at $280{ }^{\circ} \mathrm{C}$ for $3 \mathrm{~min}$.

\section{RESULTS AND DISCUSSION}

3. REZULTATI I RASPRAVA

\subsection{Weight loss of samples}

3.1. Gubitak mase uzoraka

After 14-week exposure of beech wood samples to Trametes versicolor, the average weight loss of samples was $23.7 \%$. However, Olfat (2014) indicated that the weight loss of beech wood was $47.5 \%$ after 16 weeks and $13.2 \%$ after 10 weeks.

\subsection{Results of TG analysis}

3.2. Rezultati TG analize

As observed in thermo gravimetric curves of decayed and control (undecayed) beech wood pyrolysis samples (Figure 1a, b), thermal decomposition of cellulose and lignin started at $325^{\circ} \mathrm{C}$ and $440{ }^{\circ} \mathrm{C}$, respectively.

The TGA and DTG curves of the decayed and undecayed beech wood samples are shown in Figure 1a, b. The maximum peak temperature of decayed beech wood was $325^{\circ} \mathrm{C}$ and for undecyed wood 352 ${ }^{\circ} \mathrm{C}$, which resulted in one or two prominent peaks that corresponded to the decomposition of hemicellulose and cellulose. Lignin decomposition was reached at $600{ }^{\circ} \mathrm{C}$. The DTG curves revealed that the weight loss of undecayed samples started at 228 and continued up to $600{ }^{\circ} \mathrm{C}$, while for decayed samples it started at 211 and continued up to $600{ }^{\circ} \mathrm{C}$. Furthermore, increased weight loss was observed in decayed wood, resulting in increased volatile matters.

The results of experiments on the determination of pyrolysis temperature, time and products are summarized in Table 1.

It can be seen that the decayed wood had the highest yields of gas and tar, $26.2 \%$ and $62.5 \%$, respectively, and undecayed wood $18.3 \%$ and $58.2 \%$, respectively. On the other hand, the charcoal yield was lower in decayed wood $(11.3 \%)$ in comparison to undecayed wood $(23.5 \%)$. 

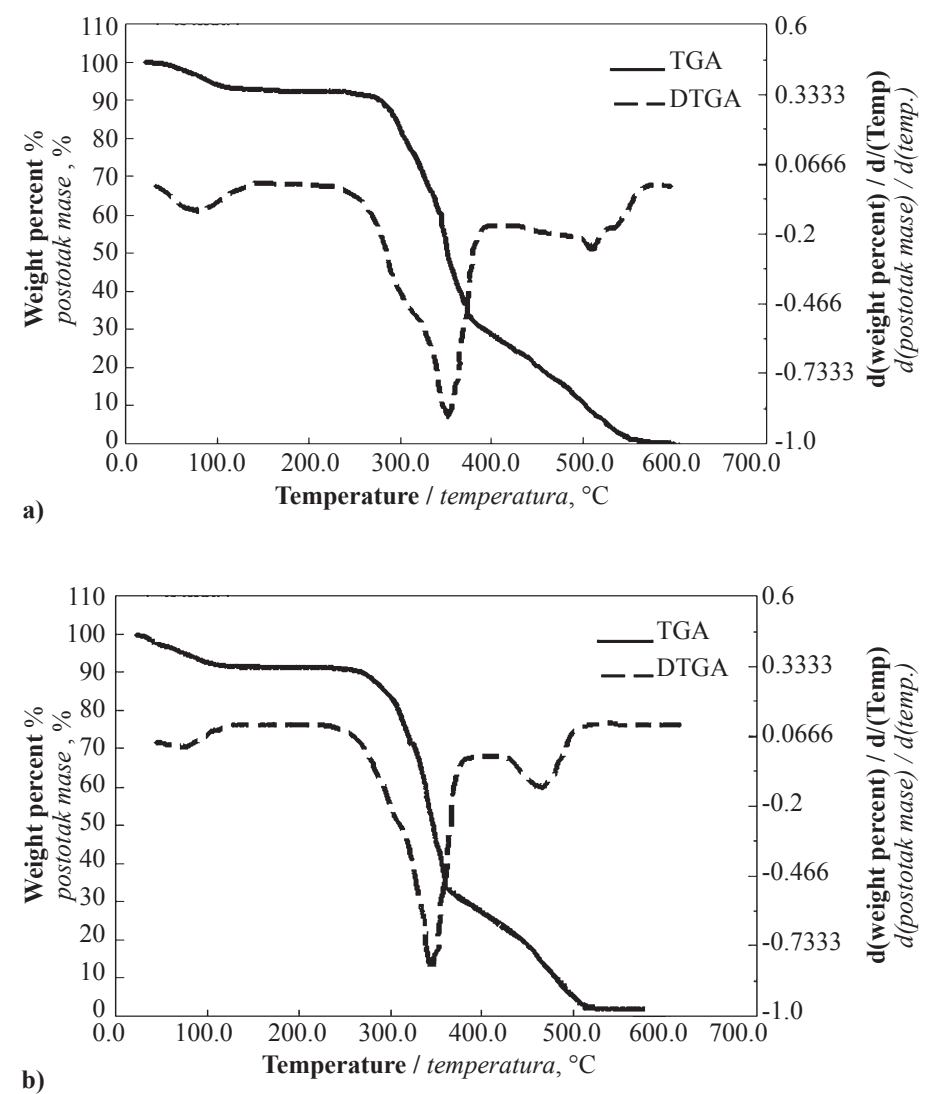

Figure 1 Thermal behavior of decayed and undecayed beech wood samples; TGA, DTGA of control (a) and decayed beech wood (b)

Slika 1. Toplinsko ponašanje uzoraka natruloga i zdravoga bukova drva: a) TGA, DTGA kontrolnog uzorka; b) TGA, DTGA natruloga bukova drva

Table 1 Charcoal, gas and tar yield of decayed and undecayed beech wood samples

Tablica 1. Udjeli ugljena, plina i katrana dobiveni pirolizom uzoraka natruloga i zdravog bukova drva

\begin{tabular}{|l|c|c|c|c|c|c|}
\hline \multicolumn{1}{|c|}{$\begin{array}{c}\text { Treatment } \\
\text { Uzorak }\end{array}$} & $\begin{array}{c}\text { Temperature } \\
\text { Temperatura } \\
{ }^{\circ} \mathrm{C}\end{array}$ & $\begin{array}{c}\text { Time } \\
\text { Vrijeme } \\
\text { min }\end{array}$ & $\begin{array}{c}\text { Initial weight of wood } \\
\text { flour / Početna masa } \\
\text { drvnog brašna } \\
\mathrm{g}\end{array}$ & $\begin{array}{c}\text { Charcoal } \\
\%\end{array}$ & $\begin{array}{c}\text { Gas } \\
\text { Plin } \\
\%\end{array}$ & $\begin{array}{c}\text { Tar } \\
\text { Katran } \\
\%\end{array}$ \\
\hline Decayed beech wood / natrulo bukovo drvo & 500 & 30 & 5 & 11.3 & 26.2 & 62.5 \\
\hline Undecayed beech wood / zdravo bukovo drvo & 500 & 30 & 5 & 23.5 & 18.3 & 58.2 \\
\hline
\end{tabular}

\subsection{Analysis of chemical compounds}

\subsection{Analiza kemijskih spojeva}

The chemical components of the wood influence its application in the production of pyrolysis products. Each component produces different products with different properties and application. Therefore, the chemical composition of both decayed and uncedayed beech wood samples are determined and summarized in Table 2.

It was reported that thermal decomposition of hemicelluloses occurs at temperatures ranging from
150 to $350^{\circ} \mathrm{C}$, while cellulose decomposes in the range of 275 to $350{ }^{\circ} \mathrm{C}$ (Hindi et al., 2010) and lignin gradually decomposes at temperatures between 250 and 500 ${ }^{\circ} \mathrm{C}$ (Essabir et al., 2013). The initial degradation between 50 and $200{ }^{\circ} \mathrm{C}$, obtained for decayed and undecayed beech wood, refers to the losses of volatile compounds and water.

The results indicate that the decayed wood contains more extractives $(4.33 \%)$ than the undecayed wood. In addition, both cellulose and lignin decreased in decayed wood $(53.33 \%$ and $28.5 \%$ ), which was

Table 2 Cellulose, Klason lignin, extractives and ash content of decayed and undecayed beech wood samples Tablica 2. Sadržaj celuloze, Klason lignina, ekstraktiva i pepela u uzorcima od natruloga i zdravoga bukova drva

\begin{tabular}{|l|c|c|c|c|}
\hline \multicolumn{1}{|c|}{$\begin{array}{c}\text { Compound } \\
\text { Spoj }\end{array}$} & $\begin{array}{c}\text { Cellulose } \\
\text { Celuloza } \\
\%\end{array}$ & $\begin{array}{c}\text { Klason Lignin } \\
\text { Klason lignin } \\
\%\end{array}$ & $\begin{array}{c}\text { Extractives } \\
\text { Ekstraktivi } \\
\%\end{array}$ & $\begin{array}{c}\text { Ash } \\
\text { Pepeo } \\
\%\end{array}$ \\
\hline Decayed beech wood / natrulo bukovo drvo & 53.33 & 28.5 & 2.3 & 2.8 \\
\hline Undecayed beech wood / zdravo bukovo drvo & 49.83 & 31 & 4.33 & 2 \\
\hline
\end{tabular}




\section{....... Hosseinihashemi, Hassani, Latibari, Özbay: Chemical Characterization of Bio-oil...}

expected as this fungus has a negative effect on these compounds.

\subsection{Analysis of GC/MS spectrums}

3.4. GC/MS analiza spektra

In order to separate and identify the oils obtained from pyrolysis of decayed beech wood, the oil was in- jected into GC/MS device after purification and derivation by BSTFA at $500{ }^{\circ} \mathrm{C}$.

According to Table 3, tetracosamethyl-cyclododecasiloxane $(5.50 \%)$, tetradecamethyl-hexasiloxane (4.85\%), 2,6-dimethoxy-phenol (syringol) (4.21\%), and benzene acetic acid (3.16\%) were the main oil

Table 3 Main organic components of bio-oils a

Tablica 3. Glavni organski sastojci biološkog ulja ${ }^{\text {a }}$

\begin{tabular}{|c|c|c|c|c|}
\hline \multirow[b]{2}{*}{ R.T. (min) } & \multirow[b]{2}{*}{$\begin{array}{l}\text { Quality } \\
\text { Kvaliteta }\end{array}$} & \multirow[b]{2}{*}{$\begin{array}{c}\text { Name of compounds } \\
\text { Naziv spoja }\end{array}$} & \multicolumn{2}{|c|}{$\begin{array}{c}\text { Area, } \% \\
\text { Površina, \% }\end{array}$} \\
\hline & & & \begin{tabular}{|c|} 
Control \\
wood oil \\
Ulje od \\
zdravog drva \\
\end{tabular} & \begin{tabular}{|c|} 
Decayed \\
wood oil \\
Ulje od \\
natrulog drva
\end{tabular} \\
\hline \multicolumn{5}{|c|}{ Aldehydes / aldehidi } \\
\hline 13.26 & 96 & $\begin{array}{l}\text { 4-Hydroxy-3-methoxy -benzaldehyde } \\
\text { 4-hidroksi-3-metoksi-benzaldehid }\end{array}$ & 1.19 & 0.85 \\
\hline \multicolumn{3}{|c|}{ Sum / zbroj } & 1.19 & 0.85 \\
\hline \multicolumn{5}{|c|}{ Acids / kiseline } \\
\hline 16.52 & 70 & Benzeneacetic acid / benzenoctena kiselina & 1.83 & 3.16 \\
\hline 19.56 & 95 & n-Hexadecanoic acid / n-heksadekanska kiselina & - & 0.36 \\
\hline 21.11 & 80 & 1,2-Benzenedicarboxylic acid / 1,2-benzendikarboksilna kiselina & - & 1.15 \\
\hline \multicolumn{3}{|r|}{ ( } & 1.83 & 4.67 \\
\hline \multicolumn{5}{|c|}{ Alcohols / alkoholi } \\
\hline 11.61 & 94 & 2-Methoxy benzenethanol / 2-metoksi benzenetanol & 1.23 & - \\
\hline \multicolumn{3}{|c|}{ Sum / zbroj } & 1.23 & - \\
\hline \multicolumn{5}{|c|}{ Ketones / ketoni } \\
\hline 7.65 & 96 & $\begin{array}{l}\text { 2-Hydroxy-3-methyl-2-cyclopenten-1-one } \\
\text { 2-hidroksi-3-metil-2-ciklopenten-1-jedan }\end{array}$ & 1.42 & 0.64 \\
\hline \multicolumn{3}{|r|}{ 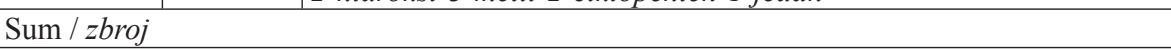 } & 1.42 & 0.64 \\
\hline \multicolumn{5}{|c|}{ Benzenes / benzeni } \\
\hline 6.59 & 91 & 1-Ethyl-3-methyl- benzene / 1-etil-3-metil-benzen & - & 0.90 \\
\hline 7.15 & 92 & 1,2,4-trimethyl- benzene / 1,2,4-trimetil-benzen & - & 0.77 \\
\hline 10.27 & 93 & Naphthalene / naftalen & 4.41 & 1.84 \\
\hline 10.56 & 95 & 1-Pentene, 3-ethyl-3-ethyl / 1-penten, 3-etil-3-etil & - & 0.79 \\
\hline 13.39 & 93 & Tetradecamethyl -hexasiloxane / tetradekametil-heksasiloksan & 2.82 & 4.85 \\
\hline \multicolumn{3}{|r|}{ (20 } & 7.23 & 9.15 \\
\hline \multicolumn{5}{|c|}{ Phenols / fenoli } \\
\hline 8.73 & 90 & 2-Methoxy-phenol / 2-metoksi-fenol & 3.60 & 1.26 \\
\hline 10.34 & 96 & 2-Methoxy-4-methyl-phenol / 2-metoksi-4-metil-fenol & 3.08 & 1.32 \\
\hline 10.47 & 96 & 2 -Trimethyl-phenol / 2-trimetil-fenol & - & 0.66 \\
\hline 11.61 & 90 & 4-Ethyl-2-methoxy-phenol / 4-etil-2-metoksi-fenol & - & 0.69 \\
\hline 12.10 & 96 & 2-Methoxy-4-vinyl-phenol / 2-metoksi-4-vinil-fenol & 1.88 & - \\
\hline 12.58 & 93 & 2,6-Dimethoxy-phenol / 2,6-dimetoksi-fenol & 14.86 & 4.21 \\
\hline 13.92 & 96 & 2-Methoxy-4-(1-propenyl)-phenol / 2-metoksi-4-(1-propenil)-fenol & 3.17 & 0.83 \\
\hline 15.78 & 97 & $\begin{array}{l}\text { 2,6-Dimethoxy-4-(2-propenyl)-phenol } \\
\text { 2,6-dimetoksi-4-(2-propenil)-fenol }\end{array}$ & 6.59 & 1.67 \\
\hline \multicolumn{3}{|c|}{ Sum / zbroj } & 33.18 & 10.65 \\
\hline \multicolumn{5}{|c|}{ Alkanes / alkani } \\
\hline 9.92 & 91 & Decamethyl-cyclopentasiloxane / dekametil-ciklopentasiloksan & 1.73 & 1.28 \\
\hline 10.55 & 94 & $\begin{array}{l}\text { 3-Cyclopropylcarbonyloxydodecane } \\
\text { 3-ciklopropilkarboniloksidodekan }\end{array}$ & 1.88 & \\
\hline 12.04 & 91 & Dodecamethyl-cyclohexasiloxane / dodekametil-cikloheksasiloksan & 0.91 & 0.59 \\
\hline 12.22 & 96 & [1,2-Phenylenebis(oxy)] silane / [1,2-fenilenebis(oksi)] silan & - & 1.39 \\
\hline 12.30 & 93 & Dodecamethyl-cyclohexasiloxane / dodekametil-cikloheksasiloksan & - & 0.63 \\
\hline 13.23 & 98 & Tetradecane / tetradekan & 2.88 & 1.81 \\
\hline 15.21 & 99 & [1,2,3-Benzenetriyltris(oxy)- silane / [1,2,3-benzentriiltris(oksi)- silan & - & 1.77 \\
\hline 15.71 & 98 & Hexadecane / heksadekan & 2.31 & 1.18 \\
\hline 17.94 & 95 & Octadecane / oktadekan & - & 0.46 \\
\hline 21.26 & 83 & $\begin{array}{l}\text { Tetracosamethylcyclododecasiloxane / tetrakozametilciklododekasilok- } \\
\text { san }\end{array}$ & 1.26 & 5.50 \\
\hline \multicolumn{3}{|r|}{ Dor } & 10.97 & 14.61 \\
\hline \multicolumn{3}{|c|}{ TOTAL / UKUPNO } & 57.05 & 40.56 \\
\hline
\end{tabular}

${ }^{a}$ Obtained at $500{ }^{\circ} \mathrm{C}$. / Dobiveno pri $500{ }^{\circ} \mathrm{C}$. 
components present in decayed beech wood after pyrolysis at $500{ }^{\circ} \mathrm{C}$

Table 3 also presents the chemical components in undecayed beech wood after pyrolysis at $500^{\circ} \mathrm{C}$, where the main components are 2,6-dimethoxy-phenol or syringol (14.86\%), 2,6-dimethoxy-4-(2-propenyl)-phenol or methoxyeugenol (6.59\%), naphthalene $(4.41$ $\%)$, 2-methoxy-phenol or $o$-guaiacol (3.60\%), 2-methoxy-4-(1-propenyl)-phenol or isoeugenol (3.17\%), and 2-methoxy-4-methyl-phenol or 4-methylguaiacol $(3.08 \%)$.

The main chemical compounds obtained at this temperature are related to phenols and phenyls, derived from thermal degradation of lignin (Faix and Jakab, 1988; Zandersons et al., 1999; Ingram et al., 2008; Mohan et al., 2008; Özçimen and Ersoy-Meriçboyu, 2010). Lignin is the most resistant polymer in wood that can be degraded by heat (Faix and Jakab, 1988). Zandersons et al. (1999) reported that polysaccharides are degraded at low temperatures.

The bio-oils obtained from control and decayed wood, analyzed by GC/MS, were widely different. The determined products are divided into the following seven categories: aldehydes, acids, alcohols, ketones, benzenes phenols and alkanes. The analysis of decayed wood bio-oils indicated that the main wood components derived from these compounds, such as phenols, aldehydes and alcohols, were lower. Phenols were the most important compounds; phenols accounted for $10.65 \%$ of the total peak areas detected in decayed wood bio-oil, while $33.18 \%$ of the total peak areas were detected in control wood bio-oil. The identified products were similar to literature data on the chemical composition of bio-oils (Chum and Black, 1990; Branca et al., 2003; Bu et al., 2012; Kantarelis et al., 2013; Özbay, 2015a; Özbay, 2015b).

\section{CONCLUSIONS}

\section{ZAKLJUČAK}

In this work, decayed and undecayed beech woods were pyrolyzed at the temperature of $500{ }^{\circ} \mathrm{C}$ to produce bio-oils. The effects of decay on the yield and composition of pyrolysis products were investigated. The main conclusions of this work are as follows:

- Decayed wood showed the highest yield of gas and tar, in comparison with the undecayed wood, while the charcoal yield was lower in decayed wood.

- The results of the GC/MS analysis showed that biooils from decayed and undecayed wood contain various chemical compounds such as phenol and guaiacol.

- It should be pointed out that pyrolysis technique is an appropriate way to extract valuable chemicals from decayed and undecayed wood.

\section{Acknowledgment - Zahvala}

The authors are grateful for the support of the Department of Wood Science and Paper Technology, Karaj Branch, Islamic Azad University.

\section{REFERENCES}

\section{LITERATURA}

1. Branca, C.; Giudicianni, P.; Di Blasi, C., 2003: GC/MS characterization of liquids generated from low-temperature pyrolysis of wood. Industrial \& Engineering Chemistry Research, 42(14): 3190-3202. https://doi.org/10.1021/ie030066d.

2. British Standard 838, 1961: Methods of tests for toxicity of wood preservatives to fungi. BSI, London.

3. Bu, Q.; Lei, H.; Wang, L.; Zhang, Q.; Tang, J.; Ruan, R., 2012: Production of phenols and biofuels by catalytic microwave pyrolysis of lignocellulosic biomass. Bioresources Technology, 108: 274-279.

https://doi.org/10.1016/j.biortech.2011.12.125.

4. Chum, H. L.; Black, S. K., 1990: Process for fractionating fast-pyrolysis oils, and products derived therefrom. In: US Patent. Midwest Research Institute, Kansas City, MO, USA.

5. Dobele, G.; Urbanovich, I.; Volpert, A., 2007: Fast pyrolysis- Effect of wood drying on the yield and properties of bio-oil. BioResources, 2(4): 698-706.

6. Essabir, H.; Nekhlaoui, S.; Malta, M.; Bensalah, M. O.; Arrakhiz, F. Z.; Qaiss, A.; Bouhfid, R., 2013: Biocomposites based on polypropylene reinforced with almond shells particles: mechanical and thermal properties. Materials Design, 51(10): 225-230.

https://doi.org/10.1016/j.matdes.2013.04.031.

7. Fagbemi, L.; Khezami, L.; Capart, R., 2001: Pyrolysis products from different biomasses: application to the thermal cracking of tar. Applied Energy, 69: 293-306. https://doi.org/10.1016/S0306-2619(01)00013-7.

8. Faix, O.; Jakab, E.; Till, F., 1988: Study on low mass thermal degradation products of mill wood lignin by thermogravimetry-mass spectrometry. Wood Science and Technology, 22(4): 323-334. https://doi.org/10.1007/BF00353322.

9. Farsi, R.; Mirshokraei, S. A., 2011: Identification of compounds obtained from pyrolysis of Juglans regia wood at $350^{\circ} \mathrm{C}$ by using GC/MS. Journal of Wood \& Forest Science and Technology, 18(2): 117-128.

10. Freel, B.; Graham, R. G., 2002: Bio-oil Preservatives; Ensyn Technologies, Inc., Greely (CA), USA.

11. Gardner, D. J.; Schultz, T. P.; Meginnis, G. D., 1985: The pyrolitic behavior of selected lignin preparation. Journal of Wood chemistry and Technology, 5(1): 85-110. https://doi.org/10.1080/02773818508085182.

12. Goktas, O.; Ozen, E.; Baysal, E.; Mammadov, R.; Alma, M. H., 2010: A research on the usage of extracts from two poisonous plants (Muscari neglectum Guss. and Gynandriris sisyrinchium (L.) Parl.) as a wood preservative. Wood Research, 55(2): 53-62.

13. Heo, S. H.; Park, H. J.; Park, Y.-K.; Ryu, C.; Suh, D. J.; Suh, Y.-W.; Yim, J.-H. Kim, S.-S., 2010: Bio-oil production from fast pyrolysis of waste furniture sawdust in a fluidized bed. Bioresource Technology, 101(1): 91-96. https://doi.org/10.1016/j.biortech.2009.06.003.

14. Hindi, S. S.; Bakhashwin, A. A.; El-Feel, A., 2010: Physico-chemical characterization of some Saudi lignocellulosic natural resources and their suitability for fiber production. Meteorology, Environment and Arid Land Agriculture Sciences, 21(2): 45-55. https://doi.org/10.4197/met.21-2.4.

15. Hosoya, T.; Kawamoto, H.; Saka, S., 2006: Oxime-trimethylsilylation method for analysis of wood pyrolysate. Journal of Analytical and Applied Pyrolysis, 77(2): 121126. https://doi.org/10.1016/j.jaap.2006.02.009.

16. Ingram, L.; Mohan, D.; Bricka, M.; Steele, P.; Strobel, D.; Crocker, D.; Mitchell, B.; Mohammad, J.; Cantrell, 
K.; Charles, U. P., 2008: Pyrolysis of wood and bark in an auger reactor: physical properties and chemical analysis. Energy \& Fuels, 22(1): 614-625. https://doi.org/10.1021/ef700335k.

17. Kantarelis, E.; Yang, W.; Blasiak, W., 2013: Production of liquid feedstock from biomass via steam pyrolysis in a fluidized bed reactor. Energy \& Fuels, 27(8): 4748-4759. https://doi.org/10.1021/ef400580x.

18. Mohan, D.; Shi, J.; Nicholas, D. D.; Pittman Jr., C. U.; Steele, P. H.; Cooper, J. E., 2008: Fungicidal values of bio-oils and their lignin-rich fractions obtained from wood/bark fast pyrolysis. Chemosphere, 71(3): 456-465. https://doi.org/10.1016/j.chemosphere.2007.10.049.

19. Obst, R. J., 1983: Analytical Pyrolysis of hardwood and softwood lignin and its use in lignin type determination of hardwood vessel elements. Journal of Wood Chemistry and Technology, 3(4): 377-397. https://doi.org/10.1080/02773818308085170.

20. Olfat, A. M., 2014: Natural durability ratings in Fagus orientalis degraded by wood-rotting Basidiomycetes, Coriolus versicolor. Advances in Environmental Biology, 8(4): 985-989.

21. Özbay, G., 2015a: Catalytic Pyrolysis of Pine Wood Sawdust to Produce Bio-oil: Effect of Temperature and Catalyst Additives. Journal of Wood Chemistry and Technology, 35(4): 302-313. https://doi.org/10.1080/02773813.2014.958240.

22. Özbay, G., 2015b: Pyrolysis of firwood (Abies bornmülleriana Mattf.) sawdust: characterization ofb-oil and biochar. Drvna industrija, 66(2): 105-114. https://doi.org/10.5552/drind.2015.1359.

23. Özçifçi, A.; Özbay, G., 2013: Bio-oil production from catalytic pyrolysis method of furniture industry sawdust.
Journal of the Faculty of Engineering and Architecture of Gazi University, 28(3): 473-479.

24. Özçimen, D.; Ersoy-Meriçboyu, A.-E., 2010: Characterization of biochar and bio-oil samples obtained from carbonization of various biomass materials. Renewable Energy, 35(6): 1319-1324.

https://doi.org/10.1016/j.renene.2009.11.042.

25. Schultz, T. P.; Nicholas, D. D., 1977: Susceptibility of angiosperm sapwood to white-rot fungal colonization and subsequent degradation. International Research Group on Wood Preservation. IRG/WP97-10211.

26. Tiilikkala, K.; Fagernas, L.; Tiilikkala, J., 2010: History and use of wood pyrolysis liquids as biocide and plant protection product. The Open Agriculture Journal, 4(1): 111-118. https://doi.org/10.2174/187433150100401011.

27. Zandersons, J.; Gravitisb, J.; Kokorevicsa, A.; Zhurinsha, A.; Bikovensa, B.; Tardenakaa, A.; Spincea, B., 1999: Studies of the Brazilian sugarcane bagasse carbonization process and products properties. Biomass and Bioenergy, 17(3): 209-219.

https://doi.org/10.1016/S0961-9534(99)00042-2.

\section{Corresponding address:}

\section{Assoc. Prof. SEYYED KHALIL HOSSEINIHASHEMI, Ph.D.}

Department of Wood Science and Paper Technology Karaj Branch, Islamic Azad University

Karaj, IRAN

e-mail: hashemi@kiau.ac.ir 